\title{
THE PROGNOSTIC INFLUENCE OF NEUROENDOCRINE CELLS IN PROSTATE CANCER: RESULTS OF A LONG-TERM FOLLOW-UP STUDY WITH PATIENTS TREATED BY RADICAL PROSTATECTOMY
}

\author{
Marinus A. NoordzIJ ${ }^{1,4}$, Theodorus H. van DER KWAST ${ }^{2}$, Gert Jan VAN STEEnBRugGE ${ }^{1}$, Wim J.C. Hop ${ }^{3}$ \\ and Fritz H. SCHRÖDER ${ }^{1}$ \\ Departments of ${ }^{1}$ Urology, ${ }^{2}$ Pathology and ${ }^{3}$ Biostatistics, Erasmus University and Academic Hospital, Rotterdam, The Netherlands.
}

\begin{abstract}
The distribution of immunohistochemically defined neuroendocrine (NE) cells in benign, pre-cancerous and neoplastic prostatic tissues and the prognostic value of these cells in prostate cancer were studied in the radical prostatectomy specimens of 90 patients from whom complete long-term follow-up data were available. The tissue blocks containing all the different Gleason patterns observed in a particular tumor were selected and immunostained. Since chromogranin B stained only a few cells compared to chromogranin $A\left(C_{g} A\right), N E$ cells were only defined by their reactivity with $\mathrm{CgA}$. A semiquantificative $\mathrm{CgA}$ score was assessed for all distinct pathological areas. Cox's regression model was used to analyze the influence of final TNM classification (TNM, 1992), Gleason sum score (GSS), age and CgA score on the probability of progression and tumor-specific death. NE cells were demonstrated in all normal prostatic tissues and in most hyperplastic and intra-epithelial neoplastic lesions. $\mathrm{CgA}$ staining was seen in $78 \%$ of the tumors. CgA scores were not related with Gleason growth patterns, GSS or TNM classification and had no prognostic value. The independent prognostic variables in Cox's regression model were: GSS and pT stage for progression and GSS for tumor-specific survival. Theoretically, NE cells could influence tumor behavior and this discrepancy suggests the need for experimental studies to investigate the role of NE cells in the normal and neoplastic prostate.

(c) 1995 Wiley-Liss, Inc.
\end{abstract}

Prostate cancer has become the most prevalent tumor in males in the western world and its mortality in those countries is only surpassed by that of lung cancer (Van der Gulden $e t$ al., 1994). A major part of prostate cancer research is directed towards the identification of prognostic factors, with the aim of better predicting individual patient outcome and optimizing treatment methods.

Neuroendocrine (NE) cells form a small, intrinsic component of normal prostatic epithelium and are also found in benign prostatic hyperplasia (BPH) and prostatic carcinoma (Aprikian et al., 1993; Di Sant' Agnese, 1992). The role of prostatic NE cells is unknown but, according to their function in better-studied organs (lungs, intestinal tract), probably concerns the maintenance of homeostasis and the regulation of secretion (reviewed by Noordzij et al., 1995). NE cells secrete neuropeptides (serotonin, calcitonin and others) and specific neuroendocrine products (chromogranins, neuronspecific enolase) (Abrahamsson et al., 1986; Aprikian et al., 1993; Di Sant' Agnese et al., 1985; Schmid et al., 1994). Prostatic NE cells are most often identified by immunohistochemical methods using specific antibodies for NE markers (e.g., chromogranin A, serotonin and neuron-specific enolase). It is important to realize that several histopathological categories of prostatic tumors with NE differentiation (i.e., containing NE cells) exist: small-cell prostatic cancer, prostatic carcinoid, adenocarcinomas with focal NE differentiation and mixed tumors (Di Sant' Agnese, 1992). The most common pattern is an ordinary adenocarcinoma with focal NE differentiation.

Several authors have reported a prognostic value of NE differentiation in prostatic adenocarcinoma (Abrahamsson et al., 1989; Bono and Pozzi, 1985; R.J. Cohen et al., 1990, 1991; Dauge and Delmas, 1987; Turbat Herrera et al., 1988). Others could not confirm these results, however (Aprikian et al., 1994; M.K. Cohen et al., 1994). The results of these studies have not been subjected to multiple regression analysis and the follow-up periods in general were relatively short. In the present long-term follow-up study, the prognostic influence of immunohistochemically defined NE cells present in radical prostatectomy specimens was studied.

\section{MATERIAL AND METHODS}

\section{Patients}

During the period 1977-1987, 144 patients underwent surgery in the Academic Hospital, Rotterdam for non-metastasized, clinically localized $\left(T_{1}-T_{2}\right)$ or locally advanced $\left(T_{3}\right)$ prostate cancer (Schröder et al., 1992). Of these, 43 patients had positive lymph nodes at operation (frozen sections of pelvic lymph nodes). None of these patients underwent radical prostatectomy, with the exception of 2 younger patients who had micrometastases. Thus, radical prostatectomy was performed on a total of 103 patients. The patients were followed regularly and, if necessary, treated during follow-up for local recurrence or metastatic disease. The mean follow-up period was 86 months. All data concerning diagnosis, radical prostatectomy, pathology and follow-up were prospectively stored in a comprehensive database. Clinical progression was defined as histologically or cytologically proven local recurrence or the appearance of distant metastases. Tumor-specific death was defined as death due to direct tumor effects or metastases or death due to tumor therapy.

\section{Tissue}

All radical prostatectomy specimens were fixed in $10 \%$ buffered formalin, $\mathrm{pH} 7.4$ and totally embedded in paraffin. All $\mathrm{H}$. and E. slides were reviewed by one pathologist (THvdK) to identify the different Gleason growth patterns, to restage the tumors (Schröder et al., 1992) and to obtain the Gleason sum scores. Only adenocarcinomas were included in the study. From each radical prostatectomy specimen the paraffin blocks containing all the different Gleason growth patterns observed in that particular tumor were selected (usually 2 to 3 blocks per tumor). If present, prostatic intra-epithelial neoplasia (PIN) was graded according to Bostwick and Brawer (1987). PIN-3 was termed high-grade PIN, whereas PIN-1 and PIN-2 were taken together as low-grade PIN. The histological material of 4 patients could not be identified and one specimen was of poor quality. Furthermore, in 5 specimens the previously diagnosed tumor could not be found (final stage $\mathrm{pT}_{0}$ ) and the remaining paraffin blocks of 3 patients no longer contained any tumor. These 13 patients were all excluded from analysis, leaving 90 evaluable patients.

${ }^{4}$ To whom correspondence and reprint requests should be sent, at Dept. of Urology, Division of Urological Oncology, Erasmus University, Room EE 1000, P.O. Box 1738, 3000 DR Rotterdam, The Netherlands.

Received: December 22, 1994 and in revised form March 21, 1995. 


\section{Immunohistochemistry}

Tissue sections of $5 \mu \mathrm{m}$ thickness were cut and mounted on 3-amino-propyl-triethoxysilane (Sigma, St Louis, MO) coated slides (Maddox and Jenkins, 1987). Following rehydration through xylene and a graded alcohol series, and blocking of the endogenous peroxidase activity with $3 \%$ hydrogen peroxide in $100 \%$ methanol, the slides were placed in a Sequenza incubator (Shandon, Runcozn, UK) and subsequently incubated with: normal goat serum (DAKO, Dakopatts, Denmark) diluted 1:10, mouse monoclonal anti-CgA (clone LK2H10, Organon, Boxtel, The Netherlands) diluted 1:60 or rabbit polyclonal anti-CgB (kind gift of Dr. R. Fischer-Colbrie, University of Innsbruck, Austria) diluted 1:750, biotinylated goat anti-mouse antibody (DAKO) for visualization of $\mathrm{CgA}$ diluted 1:400, or biotinylated goat anti-rabbit antibody (DAKO) for visualization of $\mathrm{CgB}$ diluted 1:400, and finally with peroxidase-conjugated avidin-biotin complex (DAKO) diluted 1:1: 200. All compounds were diluted in $\mathrm{pH}=7.4$ PBS. The slides were rinsed with PBS in between each step except for the step following pre-incubation. The antibody-antigen binding was visualized with $0.075 \% 3,3^{\prime}$-diaminobenzidine-tetrahydrochloride (Fluka, Neu-Ulm, Germany) with $0.08 \%$ hydrogen peroxide as substrate. The slides were lightly counterstained with hematoxylin, dehydrated and covered. Negative controls were included by replacing the primary antibody by PBS in a number of slides. Normal pancreas and normal prostatic epithelium, which was present in most tissue sections, served as positive controls.

\section{Quantification}

Tissue slides adjacent to the immunohistochemically stained slides were routinely stained with $\mathbf{H}$. and $\mathrm{E}$. and the different Gleason patterns were identified and marked. If present, BPH areas and PIN lesions were also marked. The markings were copied on to the matching areas of the immunostained slides. A cell was identified as an NE cell if a brown, granular, cytoplasmic staining pattern was visible after immunostaining. The level of NE differentiation was assessed semi-quantificatively: - , no positive cells visible; \pm , a few positive cells, widely scattered; + , some positive cells, more regularly distributed; ++ , more numerous, regularly distributed positive cells or small clusters of positive cells; +++ , numerous positive cells or larger clusters of positive cells. $\mathrm{CgA}$ scores were assessed in normal prostatic epithelium, BPH areas, low- and high-grade PIN lesions and in each Gleason pattern observed in a particular tumor. Normal, hyperplastic and PIN areas were also investigated in the specimens of the 5 patients with stage $\mathrm{pT}_{0}$ disease. If more areas from the same pathological category were identified within one prostate, the highest score was taken as the $\mathrm{CgA}$ score for that category. The tumor $\mathrm{CgA}$ score was defined as the highest $\mathrm{CgA}$ score observed in all areas of that tumor.

\section{Statistics}

Statistical analysis was performed with the SPSS and STATA computer packages. Survival tables were constructed by the Kaplan-Meier method. The log-rank test and log-rank test for trend were used in the univariate analysis. Cox's regression model was used for multivariate survival analysis. Other statistical methods were the sign test, $\chi^{2}$-test, Student's $t$-test and the Kruskal-Wallis test.

\section{Clinical}

\section{RESULTS}

The mean age of the 90 evaluable patients at operation was 62 years (range 47-74). The pre-operative staging of all patients was $\mathrm{T}_{1-3} \mathrm{~N}_{0} \mathrm{M}_{0}$. Of these, 22 patients $(24 \%)$ had a final stage of $\mathrm{pT}_{2}$, while 66 patients $(73 \%)$ and 2 patients $(2 \%)$ had $\mathrm{pT}_{3}$ and $\mathrm{pT}_{4}$ disease, respectively. Of 7 patients $(8 \%)$ with lymph-node metastasis, $5(5 \%)$ were in stage $\mathrm{pN}_{1}$ and $2(2 \%)$ were in stage $\mathrm{pN}_{2}$. The 2 patients with positive lymph nodes at operation were both staged $\mathrm{pN}_{1}$. The bottom line of Table $I$ lists the distribution of the Gleason sum scores of the 90 tumors. The mean follow-up time was 86 months (range 1-203) and 15 patients were followed for more than 120 months. During follow-up, 37 patients (41\%) showed disease progression and $14(16 \%)$ died of their tumor.

\section{Immunohistochemistry}

Immunohistochemically defined NE cells showed an intense granular cytoplasmic staining pattern (Fig. 1). However, the number of $\mathrm{CgB}$-positive cells was small compared to the number of CgA-positive cells, whether normal, benign or malignant prostatic tissues were investigated. Therefore, it was decided to define NE cells only by their immunoreactivity for $\mathrm{CgA}$. NE cells were found in all areas of normal prostatic epithelium ( $\mathrm{N}=105$, Fig. 1a). The CgA scores of the normal peri-urethral regions exceeded the CgA scores of the normal acinar regions if both were present in the $\mathrm{CgA}$ slides from one prostatectomy ( $N=18, p<0.0001, t$-test, Table II). NE cells were also found in 19 of the $23 \mathrm{BPH}$ nodules $(83 \%)$ and in lowand high-grade PIN lesions [17 out of $25(68 \%)$ and 38 out of $52(73 \%)$, respectively, Fig. $1 b]$, but the $\mathrm{CgA}$ scores of both categories were not statistically significantly different from the $\mathrm{CgA}$ scores in normal acinar epithelium ( $t$-test, $p>0.05$, Table II).

CgA staining was seen in 70 of the 90 prostatectomy specimens (78\%, Fig. 1c,d). A total of 249 Gleason patterns was examined for the presence of NE cells (2.7 per patient). The relationships between the $\mathrm{CgA}$ scores and both the primary Gleason growth patterns (sign test and $\chi^{2}$-test, Table II) and the Gleason sum scores (Kruskal-Wallis test, Table I) were not statistically significant $(p>0.05)$. Similarly, $\mathrm{CgA}$ scores did not correlate with $\mathrm{pT}$ or $\mathrm{pN}$ stage $\left(\chi^{2}\right.$-test, $\left.p>0.05\right)$.

\section{Analysis of prognostic factors}

Kaplan-Meier curves were constructed to investigate the influence of pT stage, Gleason sum score and tumor $\mathrm{CgA}$ score on the probability of progression and tumor-specific survival (Figs. 2 and 3, respectively). Univariate analysis using the log-rank test for trend showed a prognostic value of pT stage $(p=0.001)$ and Gleason sum score $(p<0.001)$ for progression and only of the Gleason sum score $(p=0.001)$ for tumor-specific survival. The other variables tested showed no statistically significant correlation with prognosis ( $\mathrm{pN}$ stage,

TABLE I - RELATION BETWEEN GLEASON SUM SCORE AND TUMOR CgA SCORE

\begin{tabular}{|c|c|c|c|c|c|c|c|c|}
\hline \multirow{2}{*}{$\begin{array}{l}\text { Tumor CgA } \\
\text { score }\end{array}$} & \multicolumn{7}{|c|}{ Gleason sum score } & \multirow{2}{*}{ Total } \\
\hline & 4 & 5 & 6 & 7 & 8 & 9 & 10 & \\
\hline- & 2 & 2 & 5 & 6 & 2 & 3 & 一 & 20 \\
\hline \pm & $\overline{3}$ & - & 7 & 13 & 4 & 6 & - & 33 \\
\hline+ & - & 2 & 3 & 10 & 1 & 3 & 1 & 20 \\
\hline++ & - & 1 & 1 & 4 & 5 & 1 & - & 12 \\
\hline$+t+$ & - & 一 & - & 3 & 1 & - & 1 & 5 \\
\hline Total & 5 & 5 & 16 & 36 & 13 & 13 & 2 & 90 \\
\hline
\end{tabular}



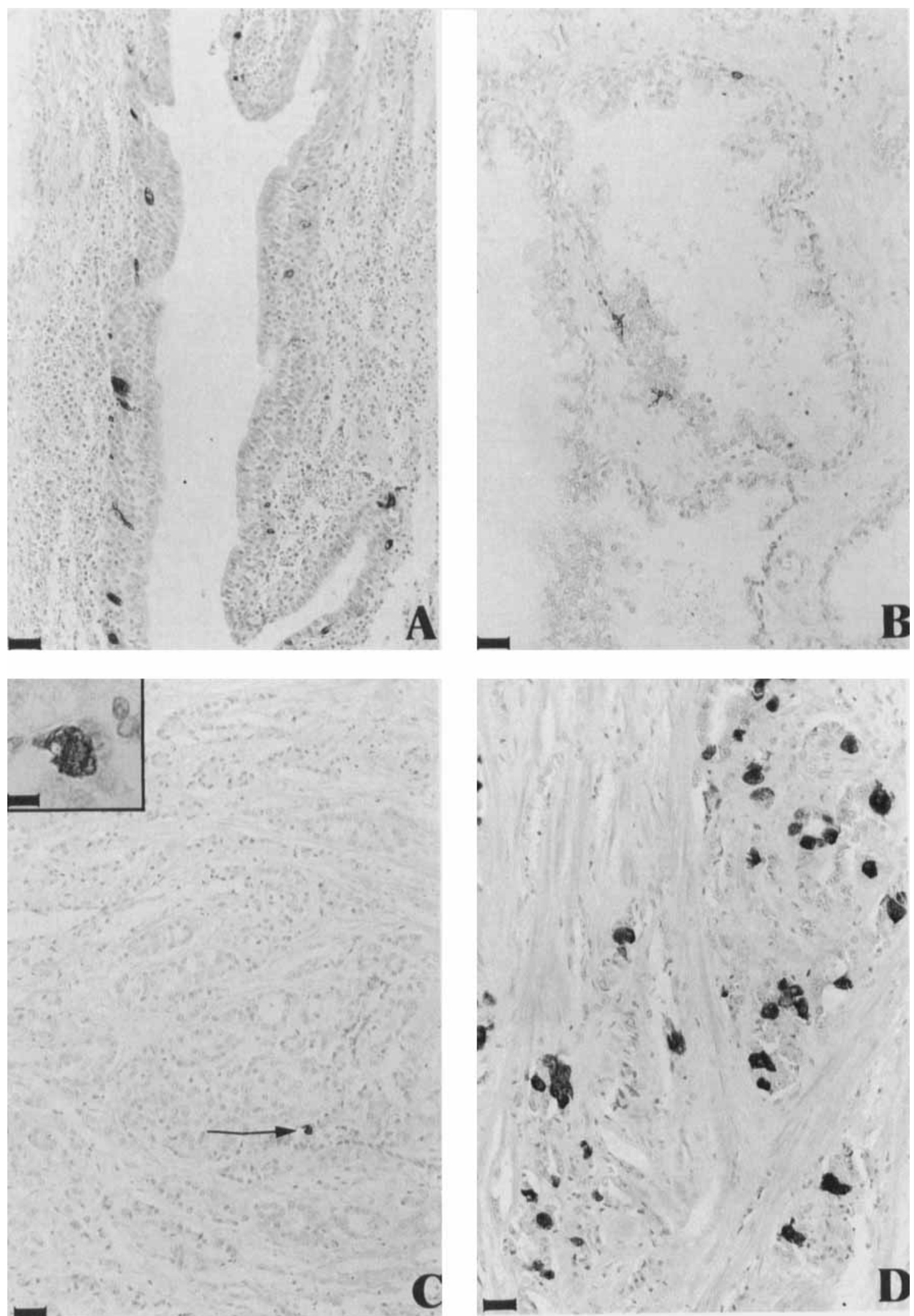

Figure 1 - CgA immunostaining. (a) Periurethral normal prostatic duct with NE cells located near the basal-cell layer. (b) High-grade prostatic intra-epithelial neoplastic lesion with basally located NE cells. (c) Primary Gleason growth pattern 4 adenocarcinoma with one $\mathrm{NE}$ cell (arrow). Inset: positive cell at higher magnification (scale bar, $6.8 \mu \mathrm{m}$ ). (d) Gleason growth pattern 4 adenocarcinoma with numerous NE cells. Scale bar, $34 \mu \mathrm{m}$. 
TABLE II - NE CELLS IN PATHOLOGICALLY DISTINCT AREAS

\begin{tabular}{|c|c|c|c|c|c|c|c|c|c|c|c|c|c|}
\hline \multirow{2}{*}{$\begin{array}{r}\mathrm{CgA} \\
\text { score }\end{array}$} & \multicolumn{3}{|c|}{ Normal } & \multirow{2}{*}{ BPH' } & \multicolumn{3}{|c|}{$\mathrm{PIN}^{2}$} & \multicolumn{6}{|c|}{ Primary Glcason growth patterns } \\
\hline & Central ${ }^{3}$ & Gland. ${ }^{4}$ & Total & & Low 5 & High $^{5}$ & Total & 1 & 2 & 3 & 4 & 5 & Total \\
\hline- & - & - & & 4 & 8 & 14 & 22 & 1 & 16 & 25 & 13 & 9 & 64 \\
\hline \pm & - & 10 & 10 & 8 & 8 & 18 & 26 & 1 & 5 & 23 & 24 & 3 & 56 \\
\hline$\overline{+}$ & 1 & 72 & 73 & 7 & 6 & 15 & 21 & 1 & - & 8 & 11 & 6 & 26 \\
\hline++ & 17 & 4 & 21 & 3 & 3 & 4 & 7 & - & - & 4 & 8 & 1 & 13 \\
\hline$++t$ & - & 1 & 1 & 1 & - & 1 & 1 & - & - & 1 & 3 & 1 & 5 \\
\hline Total & 18 & 87 & 105 & 23 & 25 & 52 & 77 & 3 & 21 & 61 & 59 & 20 & 164 \\
\hline
\end{tabular}

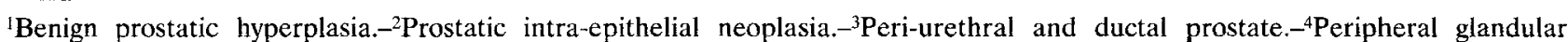
prostate. $-{ }^{5}$ Low- and high-grade PIN.

\begin{tabular}{|c|c|c|c|c|}
\hline Variable $^{1}$ & Groups & $\begin{array}{c}\text { Relative } \\
\text { Risk }^{2}\end{array}$ & $95 \% \mathrm{CI}^{3}$ & $p$ \\
\hline \multicolumn{5}{|c|}{ Probability of progression } \\
\hline Gleason sum score & $\begin{array}{c}1=4-5,2=6,3=7,4=8 \\
5=9-10\end{array}$ & 1.60 & $1.16-2.21$ & 0.004 \\
\hline pT stage & $0=\mathrm{pT}_{2}, 1=\mathrm{pT}_{3-4}$ & 3.83 & $1.07-13.6$ & 0.038 \\
\hline \multicolumn{5}{|c|}{$\begin{array}{l}\text { Probability of tumor-specific } \\
\text { death }\end{array}$} \\
\hline Gleason sum score & $\begin{array}{l}1=4-5,2=6,3=7,4=8 \\
5=9-10\end{array}$ & 2.29 & $1.41-3.74$ & 0.001 \\
\hline
\end{tabular}

"Variables coded as shown under "Groups"; only the independent prognostic factors are shown.-2The impact of a single parameter in the model on the probability of progression or tumor-specific death (Cox's regression model is an exponential function, the relative risk represents $\left.\mathrm{e}^{\text {(regression coefficient) }}\right) .-395 \%$ confidence interval of relative risk (e (regression coefficient $\pm 2 *$ standard error),$p=$ probability.

age at operation and $\operatorname{CgA}$ score). The significant parameters from the univariate analysis were entered in Cox's regression model (Table III). Both pT stage and the Gleason sum score were independent prognosticators for the probability of progression. The Gleason sum score was the only independent prognosticator to predict tumor-specific survival. Stepwise entering of the other variables did not improve the models.

\section{DISCUSSION}

$\mathrm{NE}$ differentiation in prostatic adenocarcinoma has gained increasing attention during recent years. The present study was carried out to investigate whether the extent of $\mathrm{NE}$ differentiation is an independent prognostic factor in radical prostatectomy specimens. A substantial number of patients and a long-term follow-up made it possible to study more conclusively the relation between NE differentiation, tumor stage and grade and patient age with respect to the probability of disease progression and tumor-specific death. Remarkably, the final $\mathrm{pT}$ stage of the tumors showed a relatively large proportion of $\mathrm{pT}_{3}$ tumors. At operation, 29 patients had a clinically $T_{3}$ tumor and 32 of the clinically $T_{2}$ tumors were up-staged to stage $\mathrm{pT}_{3}$. Since the treatment decision did not depend on biopsy tumor grade, the high frequency of tumors with Gleason sum scores $8-10(\mathrm{~N}=28,31 \%)$ can be explained by the observed relation between tumor stage and Gleason sum score $\left(p=0.018, \chi^{2}\right.$-test $)$, as found by Stamey et al. (1988).

Schmid et al. (1994) found that, in the more poorly differentiated prostatic tumors with NE cells, CgA expression disappeared whereas $\mathrm{CgB}$ expression increased. These results indicate that defining prostatic NE cells only by their immunoreactivity for $\mathrm{CgA}$ could lead to an underestimation of the number of NE cells in certain prostatic tumors. In the present study a new polyclonal antibody (PE-11) directed against a purified $\mathrm{CgB}$ peptide was used. $\mathrm{CgA}$ and $\mathrm{CgB}$ staining both resulted in an intense granular cytoplasmic staining. However, the number of $\mathrm{CgB}$-positive cells was very small compared to the number of CgA-positive cells, whether normal, hyperplastic or cancerous prostatic tissues were investigated. Moreover, $\mathrm{CgB}$ did not replace $\mathrm{CgA}$ expression in high-grade (Gleason primary growth patterns 4 and 5) tumors. Control tissue (normal pancreas) revealed identical results for $\mathrm{CgA}$ and $\mathrm{CgB}$. Attempts to increase $\mathrm{CgB}$ staining in prostatic tissues with pronase pre-treatment or with antigen retrieval in a microwave oven failed (Shi et al., 1991) and therefore, for the present study, it was decided to define NE cells solely by their immunoreactivity for $\mathrm{CgA}$. The number of tumors with $\mathrm{NE}$ cells might be underestimated in the present study since CgA-negative prostatic NE cells exist (Aprikian et al., 1993). On the other hand, $78 \%$ of the tumors contained NE cells and it is questionable whether this figure would increase if another marker, for instance serotonin, were included.

$\mathrm{CgA}$ scores were assessed in pathologically distinct areas to investigate their putative relationship (Table II). If present, CgA scores were also assessed in normal prostatic epithelium. All normal prostatic epithelium areas $(\mathrm{N}=105)$ contained $\mathrm{NE}$ cells, although the $\mathrm{CgA}$ scores were higher in the peri-urethral region than in the peripheral glandular region $(p<0.001$, sign-test), an observation that was also made by R.J. Cohen $e t$ al. (1993), but not by Aprikian et al. (1993). The fact that 17 of the 18 normal peri-urethral regions (94\%) had a $\mathrm{CgA}$ score of ++ and 74 of the 87 normal peripheral regions ( $85 \%$ ) had a $\mathrm{CgA}$ score of + indicates that the inter-individual variation in the number of NE cells is rather limited as far as normal prostatic epithelium is concerned. This observation could serve as an internal control for the immunohistochemical procedure. NE cells were identified in $83 \%$ of the BPH areas and in $68 \%$ and $73 \%$ of the low- and high-grade PIN lesions, respectively. The distribution of the $\mathrm{CgA}$ scores in $\mathrm{BPH}$ and PIN lesions was statistically not significantly different from that seen in normal, glandular prostatic epithelium. No relation- 

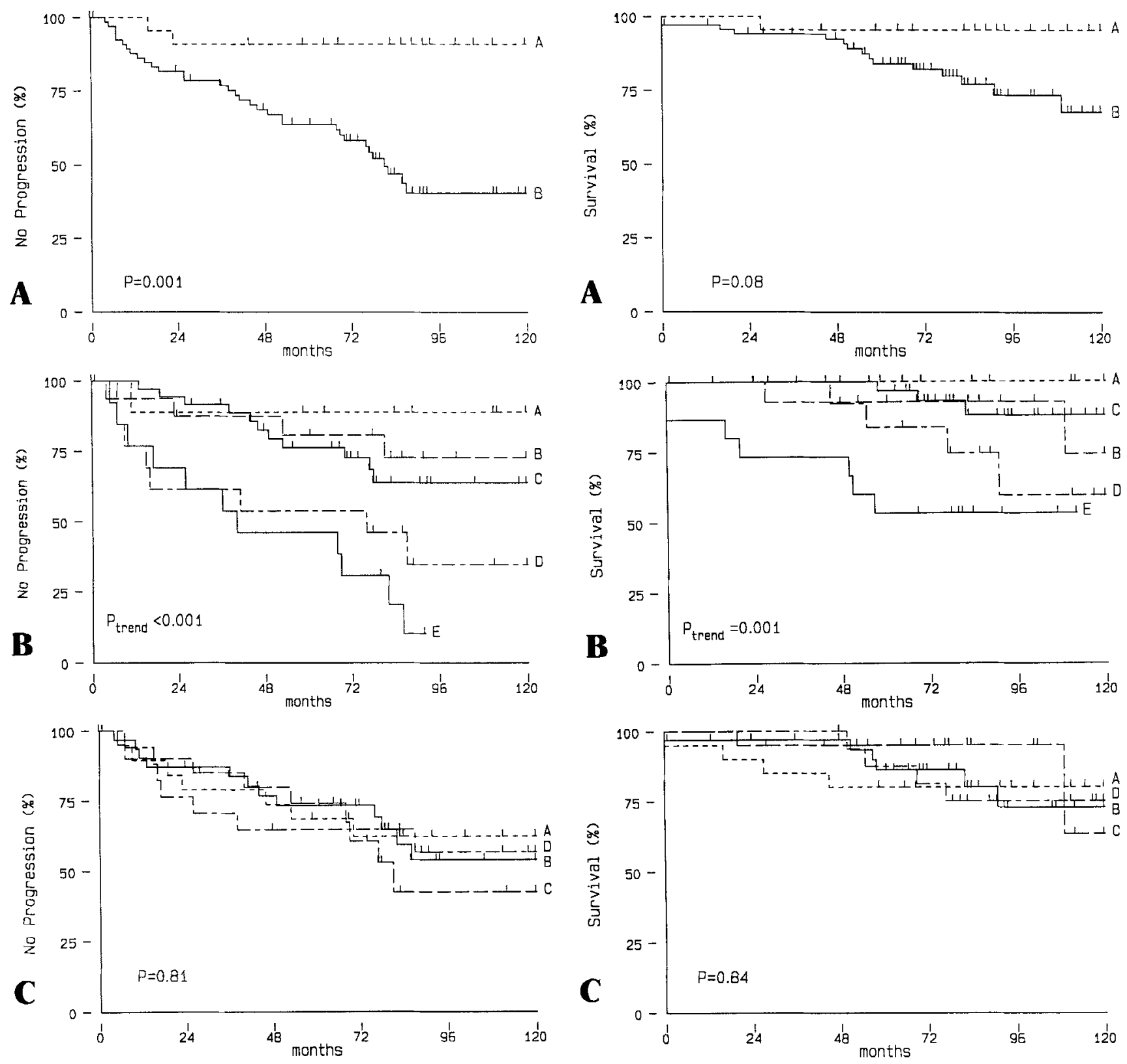

Figure 2 - Kaplan-Meier curves for progression. (a) Relation with pT stage $\left(A=\mathrm{pT}_{2} \mathrm{n}=22, \mathrm{~B}=\mathrm{pT}_{3-4} \mathrm{n}=68\right)$. (b) Relation with Gleason sum score $(A=4-5 n=10, B=6 n=16, C=7$ $\mathrm{n}=36, \mathrm{D}=8 \mathrm{n}=13, \mathrm{E}=9-10 \mathrm{n}=15$ ). (c) Relation with tumor CgA score $(A=-, n=20 ; B= \pm, n=33 ; C=+, n=20$ $\mathrm{D}=++-+++, \mathrm{n}=17$ ). Tick marks indicate censored patients Curves are truncated at 120 months (statistical analysis was performed for the complete follow-up period).

ship was found between the size of the hyperplastic nodules and the CgA scores (data not shown), whereas Cockett et al. (1993) even found an inverse relationship. It should be noted, however, that in the present study no detailed measurement of the size of the hyperplastic areas was performed.

No data concerning NE cells in PIN lesions have been published so far. The pattern of NE differentiation was identical in low- and high-grade PIN lesions, as was the distribution of $\mathrm{CgA}$ scores (Table II). NE cells in PIN lesions were in general basally located (Fig. 1b), which suggests that

Figure 3 - Kaplan-Meier curves for tumor-related death. See legend to Figure 2 for explanation.

basal cells in these lesions show a multidirectional differentiation similar to that observed in normal prostate. It is very likely, however, that the PIN-associated NE cells originate from non-neoplastic basal cells. Nevertheless, PIN-NE cells might play a role in the tumorigenesis of prostate cancer.

NE cells were found in $78 \%$ of the adenocarcinomas in the present study, a figure which is in line with the results of Aprikian et al. (1993). Other authors described smaller (R.J. Cohen et al., 1990, 1991; M.K. Cohen et al., 1994), or larger percentages (Abrahamsson et al., 1989). Differences in tissue processing, types of tissue investigated and patient characteristics probably partially account for these differences. However, M.K. Cohen et al. (1994) performed antigen retrieval (Shi et al., 1991), a method which enhances the immunostaining of a number of antibodies, including CgA clone LK2H10, and 
found NE cells in only about $30 \%$ of the specimens. The entrapment of benign NE cells in a tumor might also explain the high percentage of tumors with NE cells. However, in a tumor, only cancerous NE cells were scored positive, which makes this explanation unlikely.

The outcome of the present long-term follow-up study indicates that, in prostate cancer patients treated by radical prostatectomy, NE differentiation does not influence the probability of tumor progression or cancer-related death. Even the extent of NE differentiation, as defined by increasing tumor CgA scores (Table I), did not show a tendency towards a poor prognosis ( $p>0.05, \log$-rank test for trend). The distribution of the tumor $\mathrm{CgA}$ scores was statistically not significantly different from that of normal glandular epithelium $\mathrm{CgA}$ scores $(p>0.05, t$-test $)$. Some other recent reports also tempered initial enthusiasm regarding the prognostic influence of NE cells in prostate cancer (Aprikian et al., 1994; M.K. Cohen et al., 1994). In the study of Aprikian et al. (1994) this concerned the prognostic value of NE cells in metastatic lesions. M.K. Cohen et al. (1994) found no prognostic influence of NE cells (CgA or neuron-specific enolase positive cells) in 38 patients with clinically stage-II (AJCC) prostate cancer treated by radical prostatectomy. The follow-up period in their study was relatively short (maximum 77 months) and the relationship between tumor grade and NE differentiation was not discussed in detail. In 2 studies, R.J. Cohen et al. (1990, 1991) described a striking prognostic influence of $\mathrm{CgA}$-positive cells in initial biopsies and TUR specimens with incidental prostate cancer. Abrahamsson et al. (1989) studied the number of CgA-positive cells in repeated biopsy specimens of 24 hormonally treated patients and generally found, with time, an increase in number of $\mathrm{CgA}$-positive cells which was paralleled by dedifferentiation of the tumor. The relation between tumor grade and NE differentiation in their study, which might have explained part or all of the prognostic value, was not confirmed by Aprikian et al. (1993), and the data of the present study do not support this either. It should be stressed, however, that the study of Abrahamsson et al. (1989) was based on hormonally treated patients. Since the NE cells in normal and neoplastic prostatic tissues do not contain androgen receptors (Krijnen et al., 1993), their presence in a prostatic tumor might be related to androgen independence. The studies of Abrahamsson et al. (1989) and R.J. Cohen et al. (1990, 1991) may have been biased by the fact that only small tumor fragments were investigated (biopsies and TUR specimens containing small incidental carcinomas). Due to the widely scattered distribution of NE cells in most tumors, the likelihood of obtaining positively stained cells most probably correlates with both tumor volume and size of the investigated tumor area. Since tumor volume is a predictor of progression (Epstein et al., 1993), the prognostic value found in these studies may be partially explained by this relation. Furthermore, a substantial risk of obtaining falsenegative results exists, especially if only small numbers or small foci of positive cells are present. In the present study, Cox's regression identified both $\mathrm{pT}$ classification and Gleason sum score as independent prognosticators for progression, but only Gleason sum score for tumor-related death. This can be explained by the above-mentioned relationship between $\mathrm{pT}$ classification and Gleason sum score combined with the small number of events in the survival analysis $(\mathrm{N}=14,16 \%)$.

As mentioned above, prostatic NE cells do not express the androgen receptor and therefore are considered to be primarily androgen-independent (Krijnen et al., 1993). In addition, prostatic NE cells secrete neuropeptides and some of these peptides show growth-modulating activity (reviewed by Noordzij et al., 1995). If non-NE prostatic tumor cells contain receptors for these neuropeptides, tumor growth may be modulated by such peptides. Moreover, some neuropeptides were able to stimulate steroid receptors in a ligand-independent fashion (Power et al., 1991). It is possible that the NE cells are related with the androgen independence of a tumor. On the other hand, the presence of NE cells in prostate cancer might be simply an epiphenomenon determined, for instance, by stromalepithelial interactions. The function of NE cells in the normal and, especially, the neoplastic prostate remains largely unclear as yet and has to be clarified experimentally. Such studies, using well-defined, newly established, prostatic tumor xenograft models with NE cells are in progress at our institution.

\section{REFERENCES}

Abrahamsson, P.A., Falkmer, S., Falit, K and Grimelius, L., The course of neuroendocrine differentiation in prostatic carcinomas. An immunohistochemical study testing chromogranin $A$ as an "endocrine marker". Pathol. Res. Pract., 185, 373-380 (1989).

Abrahamsson, P.A., Wadström, L.B., Alumets, J., FalkmER, S. and GrYmelius, L., Peptide-hormone- and serotonin-immunoreactive cells in normal and hyperplastic prostate glands. Pathol. Res. Pract., 181, 675-683 (1986).

Aprikian, A., Cordon Cardo, C., Fair, W.R., Zhang, Z., F., BAzINETT, M., HAMdy, S.M. and ReUTER, V.E., Neuroendocrine differentiation in metastatic prostatic adenocarcinoma. J. Urol., 151, 914-919 (1994).

Aprikian, A.G., Cordon Cardo, C., Fair, W.R. and Reuter, V.E, Characterization of neuroendocrine differentiation in human benign prostate and prostatic adenocarcinoma. Cancer, 71, 3952-3965 (1993). Bono, A.V. and PozzI, E., Endocrine-paracrine cells in prostatic carcinoma and clinical course of the disease. Europ. Urol., 11, 195-198 (1985).

Bostwick, D.G. and BRAwer, M.K., Prostatic intra-epithelial neoplasia and early invasion in prostate cancer. Cancer, 59, 788-794 (1987).

Cockett A.T.K., Di Sant' Agnese, P.A., Gopinath, P., Schoen, S.R. and ABRAHAMSSON, P.A., Relationship of neuroendocrine cells of prostate and serotonin to benign prostatic hyperplasia. Urology, 42, 512-519 (1993).

Cohen, M.K., Arber, D. A Coffield, S, KeEgan, G.T MCClintoCK, J. and SPEIGHTS, V.O., Neuroendocrine differentiation in prostatic adenocarcinoma and its relationship to tumor progression. Cancer, 74, 1899-1903 (1994).

Comen, R.J., Glezerson, G. and Haffejee, Z., Neuro-endocrine cells-a new prognostic parameter in prostate cancer. Brit. J. Urol., 68, 258-262 (1991).

Cohen, R.J., Glezerson, G., Haffejee, $Z$ and Afrika, D, Prostatic carcinoma: histological and immunohistological factors affecting prognosis. Brit. J. Urol., 66, 405-410 (1990)

Cohen, R.J., Glezerson, G., Taylor, L.F., Grundle, H.A.J. and NAUDE, J.H., The neuroendocrine cell population of the human prostate gland. J. Urol., 150, 365-368 (1993).

Dauge, M.C. and Delmas, V., APUD type endocrine tumour of the prostate. Incidence and prognosis in association with adenocarcinoma. Prog. clin. biol. Res., 243A, 529-531 (1987).

Di SANT' Agnese, P.A., Neuroendocrine differentiation in carcinoma of the prostate-diagnostic, prognostic, and therapeutic implications. Cancer, 70, 254-268 (1992).

Di Sant' Agnese, P.A., De Mesy Jensen, K.L., Chuirukian, C.J. and AGaRWAL, M.M., Human prostatic endocrine-paracrine (APUD) cells. Arch. Pathol. Lab. Med., 109, 607-612 (1985).

Epstein, J.I., Carmichael, M., Partin, A.W. and Walsh, P.C., Is tumor volume an independent predictor of progression following radical prostatectomy? A multivariate analysis of 185 clinical stage $B$ adenocarcinomas of the prostate with 5 years of follow up. J. Urol., 149, 1478-1481 (1993).

Krisnen, J.L.M., JansSen, P.J.A., RuIZEveld DE Winter, J.A., VAN KRIMPEN, H., SCHRÖDER, F.H. and VAN DER KWAST, T.H., Do neuroendocrine cells in human prostate cancer express androgen receptor? Histochemistry, 100, 393-398 (1993).

MADDOX, P.H. and JENKINS, D. 3-Aminopropyltriethoxysilane (APES): a new advance in section adhesion. $J$. clin. Pathol., 40, 1256-1257 (1987).

NoordziJ, M.A., van Steenbrugge, G.J., van der Kwast, T.H. and SCHRÖDE, F.H., Invited Editorial: Neuroendocrine cells in the 
normal, hyperplastic and neoplastic prostate. Urol. Res., 22, 333-341 (1995).

Power, R.F., Mani, S.K., Codina, J., Conneely, O.M. and O'Malley, B.W., Dopaminergic and ligand-independent activation of steroid hormone receptors. Science (Wash.), 254, 1636-1639 (1991).

SCHMID, K.W., Helpap, B., Totsch, M., Kirchmarr, R., Dockhorn DWORNICZAK, B., BOCKER, W. and FISCHER COLBRIE, R., Immunohistochemical localization of chromogranins $A$ and $B$ and secretogranin II in normal, hyperplastic and neoplastic prostate. Histopathology, 24, 233-239 (1994).

Schröder, F.H., Hermanek, P., Denis, L., Fair, W.R., Gospodarowicz, M.K., and Pavone-Malaluso, M., The TNM classification of prostate cancer. Prostate, Suppl. 4, 12g-138 (1992).

SHI, S.R., KeY, M.E. and KalRA, K.L., Antigen retrieval in formalin- fixed, paraffin-embedded tissues: an enhancement method for immunohistochemical staining based on microwave oven heating of tissue sections. J. Histochem. Cytochem., 39, 741-748 (1991).

Stamey, T.A., McNeal, J.E., Freiha, F.S. and Redwine, E., Morphometric and clinical studies on 68 consecutive radical prostatectomies. $J$. Urol., 139, 1235-1241 (1988).

Turbat Herrera, E.A., Herrera, G.A., Gore, I., Lott, R.L., GrizZLE, W.E. and BonNIN, J.M., Neuroendocrine differentiation in prostatic carcinomas. A retrospective autopsy study. Arch. Pathol. Lab. Med., 112, 1100-1105 (1988).

VAN Der Gulden, J.W.J., Kiemeney, L.A.L.M., Verbeek, A.L.M. and StRAATMAN, H., Mortality trends from prostate cancer in The Netherlands (1950-1989). Prostate, 24, 33-38 (1994). 